\title{
Dietary Effects of Increasing Levels of Pigeon Pea Meal on Rabbit Performance
}

\author{
Kemi E. Akande ${ }^{1}$ \\ ${ }^{1}$ Department of Animal Production, Faculty of Agriculture, Abubakar Tafawa Balewa University, Bauchi State, \\ Nigeria \\ Correspondence: Kemi E. Akande, Department of Animal Production, Faculty of Agriculture, Abubakar Tafawa \\ Balewa University, Bauchi State, Nigeria. E-mail: kemi777akande@gmail.com
}

Received: March 23, 2015 Accepted: April 24, 2015 Online Published: June 15, 2015

doi:10.5539/jas.v7n7p156 URL: http://dx.doi.org/10.5539/jas.v7n7p156

\begin{abstract}
Conventional feedstuffs in Nigeria are expensive, which has led to the search for cheap and locally available unconventional feeding materials. This study was therefore conducted to determine the dietary effect of roasted pigeon pea meal (RPP) on the performance of rabbits. A total of forty weaner rabbits (20 male and 20 female) Dutch $\times$ Chinchilla rabbits with an average initial weight of $725 \mathrm{~g}$ and between 5 and 7 weeks old, were allocated into four dietary treatments. Each treatment had ten rabbits and five replicate per treatment in a completely randomized design. The process of roasting pigeon pea seeds took 3 to 5 minutes at approximately $80{ }^{\circ} \mathrm{C}$. The roasted pigeon pea meal (RPP) was used in formulating the diets used for rabbits. Treatment 1 (control) was maize-soybean based diet with $0 \%$ RPP while the other treatments contained 10, 20 and 30\% RPP in the diets respectively. Diets were formulated to be isonitrogenous and isocaloric. The experiment lasted for five weeks during which data were recorded for feed intake and body weight. The daily feed intake ranged from 42.26 to $57.60 \mathrm{~g}$; daily weight gain, 12.27 to $15.70 \mathrm{~g}$; feed conversion ratio, 3.41 to 4.67 and final live weight, 1284.00 to $1434.75 \mathrm{~g}$. None of these performance parameters were significantly affected by dietary treatments. It was therefore concluded that roasted pigeon pea (RPP) can successfully be included up to $30 \%$ in the ration of rabbits without adversely affecting performance.
\end{abstract}

Keywords: Nigeria, pigeon pea, roasted, unconventional feedstuff, weaner rabbits

\section{Introduction}

The high cost of conventional protein feedstuff in developing countries as resulted in the search for cheaper and available alternative sources for livestock feed. There is a great possibility for the exploitation and utilization of non-conventional protein plant sources. Considerable efforts are being made to utilize more diverse local sources of feed ingredients, particularly protein materials, because in many developing countries there is heavy and increasing reliance on soybean meal, fishmeal and other conventional sources of protein for animal feeding (FAO, 2004). Numerous species and varieties of plant proteins are yet to exploited or under-utilized for livestock nutrition. Some of these novel sources may have promising and desirable nutritive quality for future inclusion in animal diet. Future use of non-conventional feed ingredients in farm animal nutrition is a possibility if efficiently and properly exploited.

Legumes are important sources of protein and energy for farm animals. One of the under-utilize legumes of interest is the pigeon pea (Cajanus cajan). Pigeon pea is a useful feed source. Despite the large number of existing legume grains in Nigeria, only soybean, cotton seed cake and groundnut cake are mainly used in livestock feeding. Several other locally available species that exhibit remarkable adaptation to tropical conditions (for example bambara groundnut (Vigna subterranean (L.) Verdcourt), lima beans (Phaseolus lunatus L.), locust bean (Parkia species), African yam beans (Sphenostylis stenocarpa Hochst.), sunflower seed (Helianthus annuus L.), and pigeon pea (Cajanus cajan (L.) Millsp.) have been under-utilized and under-exploited for livestock feeding particularly in Nigeria (Apata \& Ologhobo, 1994). There is the tendency to underestimate the significance of the novel legumes that are under-exploited; this category of legumes is often classified as minor legumes, resulting from inadequate information on their nutritional qualities, uses, and cultivations. There is, therefore, the need for the exploitation of the full potential of these relatively neglected legumes for livestock feeding (Apata \& Ologhobo, 1994). 
Essentially, pigeon pea is a hardy plant that has good adaptability to a wide range of soils, additionally, it is more drought and high temperature tolerant than most common plants (Lim, 2012). This plant has a wide variation in duration taken to reach maturity. The variation in maturity has a great influence on the survival and fitness of the crop in different agro-ecological niches (Choudhary, 2011). It is also a valuable plant commonly cultivated and used in Africa, India, Thailand, Latin America, and Caribbean countries (Upadhyaya, L. J. Reddy, Gowda, K. N. Reddy, \& Singh, 2006; Choudhary, Sultana, Praptap, Nadarajan, \& Jha, 2011). Pigeon pea is a legume crop of interest to many researchers in several countries of the world for use as a source of livestock feed ingredient. The crude protein content of the seeds of pigeon pea is within the range of 18 to 25\% (Salunkhe et al., 1986; Akande, Abubakar, Adegbola, Bogoro, \& Doma, 2010). It has also been reported to be a good source of carbohydrate, minerals and vitamins (Sinha, 1977; Odeny, 2007).

The use of unconventional feedstuff for use in livestock ration has been of great interest to many researchers over several decades particularly in Nigeria were conventional feedstuffs are expensive. This has inevitably led to the search for locally available and affordable non-conventional feed ingredients. The sustainability of livestock production can be achieved by increasing the utilization of unconventional feedstuffs, thereby increasing the supply of available nutrients for livestock feeding. This will in essence consequently result in the increase in the animal protein intake of the Nigerian populace in general.

Some authors have suggested ways of increasing the low animal protein intake of Nigerians (Ademosun, 1976; Monsi, 2005). Towards achieving this, accelerated production of small animals is being promoted. Rabbit production has for some time been encouraged in Nigeria as a means of improving the daily protein intake (Ekpenyong \& Biobaku, 1986). Increased rabbit production could bridge the protein supply-demand gap and it represents one of the most economical methods of generating high-quality animal protein within the shortest possible time due to their rapid growth rate (Oduguwa, 2006).

One of the cheapest and most rapid supplier of meat, which has been neglected in Nigeria, is the rabbit (Adegbola \& Akinwande, 1981). Rabbit meat contains $21 \%$ protein, which is a higher value than for turkey (20.1\%), chicken (20\%), beef (16.3\%), lamb (15.7\%) and pork (11.9\%) (Aduku \& Olukosi, 1990). Rabbits can easily utilize the protein available in high-cellulose plants, whereas it is not economical to feed these same feedstuffs to poultry, the only animal with higher energy and protein efficiencies. In an efficient production system, rabbits can turn 20 percentage of the protein they eat into edible meat. Comparable figures for other species are 22 to 23 percentage for broiler chickens, 16 to 18 percentage for pigs and 8 to 12 percentage for beef (Food and Agriculture Organization (FAO), 1997). Rabbit meat is a wholesome, tasty product compared to most other meats. It is high in protein but low in fat, cholesterol, sodium and caloric content. The meat is white, fine-grained, delicately flavoured, nutritious and appetizing (Cheeke et al., 1982). Furthermore, it has been reported that the rabbit is suitable to raise for meat because of its high fecundity, prolificacy, short generation interval and high feed conversion ratio (De Blas \& Garvey, 1975).

There is dearth of information about the use of roasted pigeon pea as a protein source for feeding rabbits; hence the objective of the study was to evaluate the effects of increasing levels of roasted pigeon pea meal on the performance of weaner rabbits.

\section{Materials and Methods}

\subsection{Animals and Research Design}

Forty rabbits (20 male and 20 female) Dutch x Chinchilla rabbits with an average initial weight of $725 \mathrm{~g}$ and between five and seven weeks old, were used in the study. The rabbits were assigned into four dietary treatments, balancing for breed, sex and weight. Each treatment was replicated five times with each replicate having two rabbits. The experimental design was the completely randomized design. The experiment was carried out at the Rabbit Research House of the Abubakar Tafawa Balewa University, Bauchi. Bauchi town is located at latitude $13^{\circ} 30^{\prime} \mathrm{N}$ and longitude $11^{\circ} 50^{\prime} \mathrm{E}$ in the Northern Guinea and Sudan Savannah zones of Nigeria. The process of roasting pigeon pea seeds took 3 to 5 minutes at approximately $80{ }^{\circ} \mathrm{C}$. The seeds were allowed to cool and then milled in a hammer mill.

\subsection{Experimental Animals and Management}

The experiment was conducted using weaner rabbits obtained from the National Veterinary Research Institute, Vom, Plateau State, Nigeria. Two weeks prior to the arrival of the rabbits, the rabbit house and the metabolic cages were thoroughly washed and disinfected. A week before the arrival of the experimental animals, the rabbit house was fumigated. All equipment including the drinkers and feeders were also thoroughly washed. All feeders and water troughs were tightly fitted to the cages, to prevent spillage and feed wastage. 
On arrival, the rabbits were given vitalyte (multivitamin/antistress) for 5 days. The experimental animals were treated with Ivomectin to protect them against both ectoparasites and endoparasites. Animals were fed a pre-experimental diet for a period of seven days. Before the commencement of the experiment, the rabbits were weighed and allocated to the metabolic cages. Animals were provided with feed and water ad libitum. Animals were weighed on a weekly basis and feed intake was measured daily. Feed conversion ratio was calculated from the data obtained.

\subsection{Feeding Trial}

The roasted pigeon pea meal (RPP) was used in compounding the experimental diets as shown in Table 1. Treatment 1 (control) was maize-soybean based diet with 0\% RPP while the other treatments contained 10, 20 and 30\% RPP in the diets respectively. Diets were formulated to be isonitrogenous and isocaloric. The rabbits were housed in a single tier rabbit cage. The feeding trial lasted for five weeks during which data were recorded for feed intake and body weight. Data obtained from performance parameters were subjected to the analysis of variance (Steel \& Torrie, 1980).

\section{Results}

The performance parameters of rabbits fed graded levels of roasted pigeon pea meal based diets are presented in Table 2. Results on the daily feed intake showed that rabbits in the control group that received $0 \%$ dietary level of roasted pigeon pea meal (RPP) were not significantly different from those that received 10, 20 and $30 \%$ dietary levels of RPP. The daily feed intake values ranged from $42.26 \mathrm{~g}$ for rabbits on $30 \%$ RPP based diet to $57.60 \mathrm{~g}$ for those on the $10 \%$ RPP based diet. There was no significant difference in the daily weight gain of rabbits. The daily weight gain (DWG) varied from $12.27 \mathrm{~g}$ for rabbits fed $30 \% \mathrm{RPP}$ based diet to $15.70 \mathrm{~g}$ for those fed 10\% RPP based diet. Feed conversion ratios (FCR) were in the range of 3.41 to 4.67 for rabbits on 30 and $20 \%$ dietary levels of RPP respectively, the values obtained for the diets were statistically similar. Results of the final live weights (FLW) as influenced by dietary levels of roasted pigeon pea meal (RPP) were in the range of $1284.00 \mathrm{~g}$ to $1434.75 \mathrm{~g}$ for rabbits on 30 and $10 \%$ pigeon pea meal based diets, respectively. The final live weight of rabbits exhibited no significant difference among the dietary treatments. 
Table 1. Ingredient and chemical composition (\%) of roasted pigeon pea meal based diets fed to rabbits

\begin{tabular}{|c|c|c|c|c|}
\hline Ingredients & RPP $0 \%$ & RPP $10 \%$ & RPP $20 \%$ & RPP $30 \%$ \\
\hline Maize & 36.0 & 31.0 & 26.0 & 21.0 \\
\hline Soybean (full-fat) & 20.0 & 15.0 & 10.0 & 5.0 \\
\hline Pigeon pea meal & 0.0 & 10.0 & 20.0 & 30.0 \\
\hline Groundnut haulms & 15.0 & 15.0 & 15.0 & 15.0 \\
\hline Maize offal & 25.0 & 25.0 & 25.0 & 25.0 \\
\hline Bone meal & 3.0 & 3.0 & 3.0 & 3.0 \\
\hline Salt & 0.5 & 0.5 & 0.5 & 0.5 \\
\hline Mineral and vitamin premix* & 0.5 & 0.5 & 0.5 & 0.5 \\
\hline Total & 100.0 & 100.0 & 100.0 & 100.0 \\
\hline \multicolumn{5}{|l|}{ Calculated analyses } \\
\hline Crude protein & 16.25 & 16.15 & 16.05 & 16.00 \\
\hline Energy (Kcal/kg) & 2739.00 & 2724.00 & 2710.00 & 2696.00 \\
\hline Lysine $(\%)$ & 069 & 072 & 075 & 070 \\
\hline Methionine + cystine $(\%)$ & 0.51 & 0.50 & 0.50 & 0.49 \\
\hline Calcium (\%) & $\begin{array}{ll}0.01 \\
1.50\end{array}$ & 1.20 & $\begin{array}{l}0.50 \\
1.20\end{array}$ & $\begin{array}{l}0.49 \\
1.20\end{array}$ \\
\hline Phosphorus (\%) & 1.20 & 1.20 & $\begin{array}{l}1.20 \\
0.75\end{array}$ & 1.20 \\
\hline \multicolumn{5}{|l|}{ Chemical analyses } \\
\hline Dry matter & 95.32 & 94.43 & 95.47 & 95.25 \\
\hline Crude protein & 17.58 & 16.50 & 16.85 & 16.64 \\
\hline Crude fibre & 7.67 & 8.87 & 8.46 & 8.61 \\
\hline Crude fat & 5.21 & 4.92 & 4.75 & 4.00 \\
\hline Ash & 7.96 & 8.02 & 8.76 & 8.20 \\
\hline
\end{tabular}

Note. *Premix (Agricare-mix $\left.{ }^{\circledR}\right)$ supplied per kg of diet; Vitamin A 20,000 IU; Vitamin D 4,000 IU; Vitamin E 39.96 IU; Vitamin K $5.99 \mathrm{mg}$; Riboflavin $12 \mathrm{mg}$; Vitamin $\mathrm{B}_{12} 0.1 \mathrm{mg}$; Pyridoxine $\mathrm{HCl} 7 \mathrm{mg}$; Cal-D-Panthothenate $30 \mathrm{mg}$ Nicotinic acid $70 \mathrm{mg}$; Folic acid $2 \mathrm{mg}$; Biotin $0.2 \mathrm{mg}$; Potassium $0.41 \%$; Sodium 0.30\%; Copper $24 \mathrm{mg}$; Manganese $110 \mathrm{mg}$; Zinc $100 \mathrm{mg}$; Iron $110 \mathrm{mg}$; Selenium $0.3 \mathrm{mg}$; Calcium $0.22 \mathrm{mg}$; Iodine $3 \mathrm{mg}$; Choline $1000 \mathrm{mg}$; Butylated hydroxytoluene (BHT) $140 \mathrm{mg}$ and Zeolex $50 \mathrm{mg}$.

Table 2. Effect of graded dietary levels of roasted pigeon pea meal on performance of rabbits

\begin{tabular}{llllll}
\hline \multirow{2}{*}{ Parameters } & \multicolumn{5}{c}{ Dietary levels of RPP $(\%)$} \\
\cline { 2 - 5 } & 0 & 10 & 20 & 30 & SEM \\
\hline Initial live weight $(\mathrm{g})$ & 865 & 788 & 875 & 748 & $56.0^{\mathrm{NS}}(\mathrm{P}>0.05)$ \\
Final live weight $(\mathrm{g})$ & 1389 & 1435 & 1420 & 1284 & $96.0^{\mathrm{NS}}(\mathrm{P}>0.05)$ \\
Daily feed intake $(\mathrm{g})$ & 54 & 58 & 54 & 42 & $2.2^{\mathrm{NS}}(\mathrm{P}>0.05)$ \\
Daily weight gain $(\mathrm{g})$ & 14 & 16 & 13 & 12 & $1.1^{\mathrm{NS}}(\mathrm{P}>0.05)$ \\
Feed conversion ratio & 4 & 4 & 5 & 3 & $0.2^{\mathrm{NS}}(\mathrm{P}>0.05)$ \\
\hline
\end{tabular}

Note. $\mathrm{SEM}=$ Standard error of mean; $\mathrm{NS}=$ Not significant.

\section{Discussion}

The benefits of the dietary inclusion of pigeon pea meal in livestock rations have been documented by several researchers. Studies conducted by Corriher et al. (2010) revealed that pigeon pea may be incorporated in diets of dairy cows by replacing corn and soybean meal without adverse effect on milk production, dry matter intake and ruminal environment. Akintunde, Omage, and Bawa (2013); Onu, Nwakpu, and Okongwu (2006); Amaefule and Obioha (2005) reported that pigeon pea can be utilized as an alternative feedstuff to conventional protein sources in diets for broilers. The results obtained from the research study carried out by Igene, Isika, Oboh, and Ekundayo (2012) showed that broiler chickens at both starter and finisher phases can be fed diets containing up 
to $40 \%$ pigeon pea meal substituting soybean meal without decreasing live weight gain. Oso et al. (2012) reported that dietary inclusion of up to $50 \mathrm{~g} / \mathrm{kg}$ of pigeon pea meal could be used in the diet of cockerel chicks without imposing any threat on nutrient digestibility and growth response. Yisa, Yakubu, Edache, Danjuma \& Deme (2013) fed heat-treated pigeon pea meal to Japanese quails (Cortunix conturnix japonica) and recommended 10\% inclusion level for optimum performance. Iorgyer, Carew, and Ayoade (2008) reported that pigeon pea can be incorporated in diets of rabbits without any adverse effect on productive performance. Additionally, Akande and Adeleye (2013) encouraged the inclusion of pigeon pea meal in rabbit rations.

These findings are consistent with that of Ani and Okeke (2003), who fed roasted pigeon pea meal to broilers and reported that there was a non-significant dietary treatment effect on the broilers. Amaefule and Nwaokoro (2002) also made a similar observation when they fed graded dietary levels of pigeon pea meal to weaner rabbits. Daily weight gain of rabbits fed graded levels of RPP showed no significant difference among dietary treatments. Daily weight gain (DWG) varied from $12.27 \mathrm{~g}$ for rabbits on $30 \% \mathrm{RPP}$ based diet to $15.70 \mathrm{~g}$ for those on $10 \%$ RPP based diet. The result is similar to the range of 13.49-15.44 g reported by Iorgyer et al. (2008). Feed conversion ratio (FCR) was in the range of 3.41 to 4.67 for rabbits fed 30 and $20 \%$ dietary inclusion levels of RPP respectively, and these values were not significantly different from each other. The final live weight of rabbits was not significantly affected by dietary treatments, this is in agreement with the findings of Amaefule and Nwaokoro (2002), and Ani and Okeke (2003). These researchers reported a non-significant dietary effect of pigeon pea seed meal on feed conversion ratio and final live weight of their experimental animals. These results are consistent with that of with the recent research report of Amaefule, Onuwuchuruba, and Okereke (2013), these workers recorded successful inclusion of up to $30 \%$ pigeon pea seed meal in pullet rations. The results obtained in this study for daily feed intake (DFI), daily weight gain (DWG), feed conversion ratio (FCR) and final live weight (FLW) agree with the findings of Iheukwumere, Onyekwere, and Egu (2008) who reported that the DFI, DWG, FCR and FLW of rabbits fed diets containing heat processed pigeon pea meal were not significantly different from the control diet. Amaefule, Ihekwumere, and Nwaokoro (2005) also obtained a non-significant dietary treatment effect on all performance parameters measured when they fed varying levels of pigeon pea meal to rabbits. Likewise, Ani (2008) reported the inclusion of pigeon pea up to $30 \%$ in the diets of growing rabbits without deleterious effect on performance. The findings of this study however, contradicts that of Etuk, Udedibie, and Obikaonu (2002) who reported that there were significant differences in daily feed intake, daily weight gain, feed conversion ratio and final live weight of broiler finisher birds fed graded levels of pigeon pea meal. Ani and Okeke (2011) from the outcome of feeding pigeon pea meal to broiler chicken recommended the inclusion of roasted pigeon pea meal in broiler starter and finisher diets at $26 \%$ and $27 \%$ levels, respectively, with no deleterious effect on growth performance.

\section{Conclusion}

Sources of protein for animal feeds are many and varied, with considerable opportunities for further diversification and substitutions. More research is required on alternative sources before many of the opportunities can be exploited in practice (FAO, 2004). The exploitation of a wide range of locally available unconventional tropical legumes for successful livestock feeding in sub-Saharan Africa in general and in Nigeria, in particular, is possible but there is the need for research to provide for more successful practical exploitation. There is considerable potential in the utilization of pigeon pea in practical rabbit feeding, from the research findings of this study. The results obtained from the experiment indicate that roasted pigeon pea meal (RPP) could be included up to $30 \%$ in the diets of rabbits without negatively influencing the performance of rabbits.

It is therefore, concluded from the results of this study that there is great potential and possibility of dietary inclusion of roasted pigeon pea meal an unconventional feed stuff in rabbit feed in the future, particularly in those countries where pigeon pea is locally available and affordable and where conventional feed ingredients are expensive. Greater utilization of unconventional locally available feed sources should be encouraged for resource-poor smallholder farmers for increasing animal production in Nigeria and other developing countries.

\section{References}

Adegbola, T. A., \& Akinwade, V. O. (1981). Energy Requirement of Rabbits in the Humid Tropics. Journal of Animal Production Research, 1, 147-155.

Ademosun, A. A. (1976). The Livestock Sub-sector in the Third National Development Plan. Nigerian Journal of Animal Production, 3, 10-17.

Aduku, A. O., \& Olukosi, J. O. (1990). Rabbit Management in the Tropics. Production, Processing, Utilization, Marketing, Economics, Practical Training, Research and Future Prospects (pp. 1-3). Living Books Series G. U. Publication, Abuja, Nigeria. 
Akande, K. E., \& Adeleye, O. O. (2013). Performance of rabbits fed graded levels of roasted pigeon pea meal (p. 42). Proceedings of the British Society of Animal Science.

Akande, K. E., Abubakar, M. M., Adegbola, T. A., Bogoro, S. E., \& Doma, U. D. (2010). Chemical Evaluation of the Nutritive Quality of Pigeon Pea (Cajanus cajan (L.) Millsp). International Journal of Poultry Science, 9 , 63-65. http://dx.doi.org /10.3923/ijps.2010.63.65

Akintunde, A. R., Omage, J. J., \& Bawa, G. S. (2013). Effects of allzyme $s^{R}{ }^{R}$ Supplementation of differently processed pigeon pea (Cajanus cajan) seeds on performance and carcass characteristics of broiler chickens. Nigeria Journal of Animal Science, 15, 83-94.

Amaefule, K. U., \& Nwaokoro, C. C. (2002). The effect of graded levels of raw pigeon pea (Cajanus cajan) seed meal on the performance of weaner rabbits. In V. A. Aletor \& G. E. Onibi, (Eds.), Increasing household protein consumption through improved livestock production (pp. 113-115). Proceedings of the $27^{\text {th }}$ Annual Conference of Nigerian Society for Animal Production (NSAP), March 17-21, Akure.

Amaefule, K. U., \& Obioha, F. C. (2005). Performance and nutrient utilization of broiler starters fed diets containing raw, boiled or dehulled pigeon pea seed (Cajanus cajan). Nigerian Journal of Animal Production, 28, 31-39.

Amaefule, K. U., Iheukwumere, F. C., \& Nwaokoro, C. C. (2005). A note on the growth performance and carcass characteristics of rabbits fed graded dietary levels of boiled pigeon pea seed (Cajanus cajan). Livestock Research for Rural Development, 17, 48.

Amaefule, K. U., Onuwuchuruba, C. F., \& Okereke, O. C. (2013). Replacement value of soyabean meal and maize with raw or boiled pigeon pea seed meal in exotic pullet diets. Nigerian Journal of Animal Science, $15,37-48$.

Ani, A. O. (2008). The effect of feeding graded levels of cooked pigeon pea (Cajanus cajan) seed meal on the performance and carcass characteristics of growing rabbits. Journal of Tropical Agriculture, Food, Environment and Extension, 7, 229-234.

Ani, A. O., \& Okeke, G. C. (2003). The substitution of pigeon pea (Cajanus cajan) seed meal for soyabean in broiler finisher ration. In E. A. Olatunji, B. A. Ayanwale, E. L. Shiawoya, \& A. Aremu (Eds.), Sustainable livestock productivity and national development: The holistic approach (pp. 10-12). Proceedings of the $8^{\text {th }}$ Annual Conference of Animal Science Association of Nigeria (ASAN), September 16-18, Federal University of Technology Minna, Niger State, Nigeria.

Ani, A. O., \& Okeke, G. C. (2011). The performance of broiler birds fed varying levels of roasted pigeon pea (Cajanus cajan) feed meal. Pakistan Journal of Nutrition, 10, 1036-1040. http://dx.doi.org/10.3923/pjn.2011.1036.1040

Apata, D. F., \& Ologhobo, A. D. (1994). Biochemical evaluation of some Nigerian legume seeds. Food Chemistry, 49, 333-338. http://dx.doi.org /10.1016/0308-8146(94)90001-9

Cheeke, P. R., Patton, N. M., \& Templeton, G. S. (1982). Rabbit production (p. 328). The Interstate Printers and Publishers, inc. Danville, Illinois.

Choudhary, A. K. (2011). Effects of pollination control in pigeon pea and their implication. Journal of Food Legumes, 24, 50-53.

Choudhary, A. K., Sultana, R., Pratap, A., Nadarajan, N., \& Jha, U. C. (2011). Breeding for abiotic stresses in pigeon pea. Journal of Food Legumes, 24, 165-174.

Corrriher, V. A., Hill, G. M., Bernard, J. K., Jenkins, J. C., West, J. W., \& Mullinx, Jr., B. G. (2010). Pigeon pea as a supplement for lactating dairy cows fed corn silage-based diets. Journal of Dairy Science, 93(11), 5309-5317. http://dx.doi.org /10.3168/jds.2010-3182

De Blas, J. C., \& Garvey, J. P. (1975). A note on the retention of energy and nitrogen in rabbits. Animal Production, 21, 345-347. http://dx.doi.org/10.1017/S0003356100030828

Ekpenyong, T. E., \& Biobaku, W. O. (1986). Growth response of rabbits fed with activated sewage sludge and dried poultry waste. Journal of Applied Rabbit Research, 9, 14-16.

Etuk, E. B., Udedibie, A. B. I., \& Obikaonu, H. O. (2002). Replacement value of cooked pigeon pea (Cajanus cajan) seed meal for soybean meal and maize in broiler finisher diet. In A. O. Fanimo \& J. A. Olanite (Eds.), Contributory role of animal production in national development (pp. 157-160). Proceedings of the $7^{\text {th }}$ Annual Conference of Animal Science Association of Nigeria (ASAN), September, 16-19, University of 
Agriculture, Abeokuta, Nigeria.

Food and Agriculture Organization (FAO). (1997). The Rabbit: Husbandry, Health and Production (p. 205). David Lubin Memorial Library cataloguing in publication data.

Food and Agriculture Organization (FAO). (2004). Protein Sources for the Animal Feed Industry. FAO United Nations Animal Production and Health Proceedings. Expert Consultation and Workshop. ix-xxv. Retrieved from ftp://ftp.fao.org/docrep/fao/007/y5019e/y5019e00.pdf

Igene, F. U., Isika, M. A., Oboh, S. O., \& Ekundayo. (2012). Replacement value of boiled pigeon pea (Cajanus cajan) on growth performance, carcass and haematological responses of broiler chickens. Asian Journal of Poultry Science, 6, 1-9. http://dx.doi.org/10.3923/ajpsaj.2012.1.9

Iheukwumere, F. C., Onyekwere, M. U., \& Egu, U. E. (2008). Growth, carcass and reproductive characteristics of male rabbits (bucks) fed raw and boiled pigeon pea seed (Cajanus cajan) meal. Pakistan Journal of Nutrition, 7, 17-20. http://dx.doi.org /10.3923/pjn.2008.17.20

Iorgyer, M. I., Carew, S. N., \& Ayoade, J. A. (2008). The replacement value of pigeon pea (Cajanus cajan) for maize in weaner rabbit diets. Repositioning Animal Agriculture for the Realization of National Vision 2020 (pp. 456-459). Proceedings of the $13^{\text {th }}$ Annual Conference of the Animal Science Association of Nigeria, September 15-19, Zaria, Nigeria.

Lim, T. K. (2012). Edible Medicinal and Non-Medicinal Plants: Volume 2, Fruits. Springer Science Business Media pg 550. Retrieved from https://books.google.co.uk/books?id=4MDEqFGeKVoC

Monsi, A. (2005). The alimentary divide: feathered bipeds-A bridging causeway (pp. 1-16). Rivers State University of Science and Technology, Port-Harcourt, Nigeria. Retrieved from http://www.rsust.edu.ng/the--alimentary-divide.htm

Odeny, D. A. (2007). The potential of pigeon pea (Cajanus cajan (L.) Millsp.) in Africa. Natural Resources Forum, 31, 297-305. http://dx.doi.org/10.1111/j.1477-8947.2007.00157.x

Oduguwa, O. O. (2006). Utilization of whole pods of Albizia saman in diets of growing rabbits. Nigerian Journal of Animal Production, 33, 197-202.

Onu, P. N., Nwakpu, P. E., \& Okongwu, S. N. (2006). Effect of processing on the nutritive value of pigeon pea (Cajanus cajan) seeds for finisher broilers. International Journal of Agriculture and Rural Development, 7 , 37-43. http://dx.doi.org /10.4314/ijard.v7i1.2616

Oso, A. O., Idowu, O. M. O., Jegede, A. V., Olayemi, W. A., Lala, O. A., \& Bamgbose, A. M. (2012). Effect of dietary inclusion of fermented pigeon pea (Cajanus cajan) meal on growth apparent nutrient digestibility and blood parameters of cockerel chicks. Tropical Animal Health Production, 44(7), 1581-1586. http://dx.doi.org /10.1007/s11250-012-0109-1

Salunkhe, D. K., Chavan, J. K., \& Kadam, S. S. (1986). Pigeon Pea as Important Food Source. Critical review. Food Science and Nutrition, 23(2), 103-141. http://dx.doi.org/10.1080/10408398609527422

Sinha, S. K., (1977). Food legumes: Distribution, adaptability and biology of yield. Plant production and protection paper 3 (p. 102). Food and Agriculture Organization (FAO), Rome.

Steel, R. G. D., \& Torrie, J. H. (1980). Principle and procedure of statistics. A biometrical approach (2nd ed.). McGraw-Hill book company.

Upadhyaya, H. D., Reddy, L. J., Gowda, C. L. L., Reddy, K. N., \& Singh, S. (2006). Development of a mini core subset for enhanced and diversified utilization of pigeon pea germplasm resources. Crop Science, 46(5), 2127-2132. http://dx.doi.org /10.2135/cropsci2006.01.0032

Yisa, A. G., Yakubu, B., Edache, J. A., Danjuma, M. N., \& Deme, H. I. (2013). Effect of graded levels of toasted pigeon pea [Cajanus cajan (L.) Millsp] seed meal diets on growth performance and carcass characteristics of Japanese quails (Coturnix coturnix japonica). International Journal of Poultry Science, 12(2), 121-125. http://dx.doi.org /10.3923/ijps.2013.121.125

\section{Copyrights}

Copyright for this article is retained by the author(s), with first publication rights granted to the journal.

This is an open-access article distributed under the terms and conditions of the Creative Commons Attribution license (http://creativecommons.org/licenses/by/3.0/). 